\title{
HUMANITARIAN DILEMMAS IN A MOBILE WORLD
}

Tom Scott-Smith ${ }^{*}$

\begin{abstract}
This special issue of Refugee Survey Quarterly presents the experiences of frontline staff in Médecins Sans Frontières (MSF) as they grapple with the implications of the global refugee crisis. Over the past eighteen months hundreds of thousands of people have moved from Africa and the Middle East to Europe, generating widespread media attention and considerable political wrangling. But for aid workers, this situation raises questions that get to the very heart of humanitarianism and its purpose in the contemporary world. How does an organisation like MSF, the pioneer of 'sansfrontierism', engage with the shifting politics of borders and migration? What, practically, does it mean to be a 'borderless' organisation in a world where migration controls are such a big political issue? What are the implications of the refugee crisis for humanitarian principles and medical care? This introduction to the special issue brings some humanitarian dilemmas into focus, arguing that, in reaction to the migration crisis, aid agencies may have no option but to take a more robustly political approach.
\end{abstract}

Keywords: Humanitarian Principles, Refugees, Neutrality, Solidarity

\footnotetext{
* Associate Professor of Refugee Studies and Forced Migration, Refugee Studies Centre, University of
} Oxford. 


\section{Introduction}

In the summer of 2015, during the peak of the European refugee crisis, Antonio Guterres, the United Nations High Commissioner for Refugees (UNHCR) declared that "there is no humanitarian solution to this tragic humanitarian crisis". 1 This phrase was first popularized in the 1990s, and it has become something of an article of faith within the UN refugee agency. ${ }^{2}$ It was favoured by former high commissioner Sagata Ogata, and appeared in many public statements throughout her term of office, although she usually formulated the phrase in a slightly different way, saying that "there are no humanitarian solutions to humanitarian problems”. The point of the adage, however, has always been clear. As Ogata herself explained in an interview for the UN department of public information, the phrase was meant to articulate how UNHCR could "give protection to people, security, food, a little stability and so on, but the causes were all political”. Using a simile to clarify the point, she said it was a bit like "a fire engine running all the time without extinguishing the source of the fire itself". ${ }^{3}$

As a way to articulate the need for political engagement and the inadequacy of humanitarian assistance, Ogata’s phrase remains justifiably popular. It encapsulates how humanitarian aid, on its own, cannot solve the underlying causes of a crisis. In light of events in Europe over the summer of 2015, when thousands died crossing the Mediterranean and many more people experienced terrible suffering in detention or during lengthy journeys overland, the high commissioners' adage is apt. Aid agencies may be able to provide relief, but they cannot address the central cause of the problem. Indeed, humanitarian organizations are very limited in what they can do. They cannot tackle the state fragility that causes people to flee; they cannot alter the restrictive border regimes that force refugees to take dangerous journeys; they cannot prevent the many

\footnotetext{
${ }^{1}$ L. Doucet, “Migrant crisis: Why is it erupting now?”, BBC News Online, 13 September 2015. Available at: http://www.bbc.co.uk/news/world-middle-east-34224619 (last visited 2 Dec. 2015).

${ }^{2}$ For similar remarks see UNHCR Press release, "Remarks by António Guterres, United Nations High Commissioner for Refugees. Conference on the Syrian Refugee Situation”, 28 October 2014. Available at: http://www.unhcr.org/544fb4189.html (last visited 2 Dec. 2015) and "UNHCR head calls for urgent political solution to Iraq's deepening crisis”, 18 July 2014. Available at: http://www.unhcr.org/53c91bbb6.html (last visited 2 Dec. 2015).

${ }^{3}$ S. Ogata, interviewed by Mary Alice Williams, World Chronicle Programme no. 970 . Recorded $14^{\text {th }}$ March 2005. Available at: http://www.un.org/webcast/pdfs/wc970.pdf (last visited 6 Dec. 2015).
} 
deaths from drowning in leaky boats at sea. The situation over the summer of 2015 had causes that were inescapably political, forcing aid agencies to come to terms with their limitations, able only to attend to the immediate manifestations of a deep-seated, systemic crisis.

This special issue of the Refugee Survey Quarterly presents the experiences of frontline staff in Médecins Sans Frontières (MSF) as they grapple with these circumstances. It offers reflections from aid workers who have been providing humanitarian solutions to the global refugee crisis, despite the high commissioners' adage. As the crisis has intensified over the past two years and hundreds of thousands of people have moved from Africa and the Middle East to Europe, the implications for humanitarianism are beginning to become clearer. The papers in this issue discuss such implications, examining, among other things, the future of classical humanitarian principles, the technical challenges of offering medical assistance to people on the move, and the ethical and operational implications of working in a world where borders have become a central cause of human suffering. These and other cross cutting issues will be explored in this introduction, but at the same time, the purpose of this paper is to offer some reflections on the nature of politics and humanitarian action in the $21^{\text {st }}$ Century. I will advance an argument about the nature of contemporary humanitarianism that partly emerges from the papers that follow, but also stands apart.

The core of my argument is simply stated: that it is difficult, if not impossible, to take effective humanitarian action in response to migration without also taking a clearly political stand. The question for humanitarian agencies, therefore, is not whether to be political, but what kind of politics to promote. The debates around migration and border regimes are inherently political, so responding to suffering in accordance with the classical ideal - neutrally, impartially, independently - is neither possible, nor particularly desirable. I will elaborate on this argument later on in this paper, and in doing so I will relate the argument back to the high commissioner's adage, but my point, in essence, is that Guetteres and Ogata have placed the wrong emphasis in their interpretation of that attractive phrase ("there are no humanitarian solutions to humanitarian problems”). The key issue in contemporary humanitarianism, I will argue, is not that humanitarian solutions are insufficient. It is that humanitarian problems are 
insufficient. Framing an issue as a distinctly humanitarian one necessarily limits the responses available. Seeing inescapably political issues as humanitarian ones, in other words, can seriously curtail the possibilities for reducing suffering, and nowhere is this more evident than in the recent migration crisis.

Staff at Médecins Sans Frontières will not necessarily share all the arguments I make in this introduction, although at every stage of the process I have been indebted to individuals in the organization for exchanging perspectives and ideas. Indeed, one of the privileges of being involved in this special issue has been the opportunity to engage as an outsider - as a longstanding supporter and donor of MSF, but someone who has never formally worked for the organization. As an outsider, I have been constantly inspired and challenged by MSF, and perhaps the most refreshing part of working with this organization has been its willingness to allow internal debates to enter the public domain: embracing, and even encouraging, diversity of opinion. All the papers in this issue reveal, in some way or another, differences within the MSF movement. In a world where the humanitarian sector is increasingly concerned with managing its public image and constraining the passage of critical voices, this critical openness is a very important and exceptional quality.

Before proceeding any further, I have a few words of thanks: to Vincent Chetail for encouraging and supporting this special issue, and for the tireless and attentive work of Linn Biörklund and Hernan Del Valle. Indeed, my role in editing these articles came relatively late in the process, and it was Linn Biörklund, in particular, who had the vision and energy to push the project to fruition in the crucial early stages. I was brought in partly to help translate between the academic and the practitioner worlds, which is not always a straightforward matter, since terminology, references and stylistic traits are often so different, and although the final papers may not always be written in the style familiar to readers of Refugee Survey Quarterly, I think it is clear that there are many things scholars can learn from practitioners working on the frontline. Indeed, these papers emerge from the kind of practical, experiential knowledge that is often lacking when scholars debate such issues on the more conceptual level. The data, if we wish to call it that, is the daily world of the humanitarian worker; the analysis is a form of autoethnographic encounter; the authority of the authors emerges from what James Scott 
describes as metis, that hands-on skill and wisdom acquired from experience. Yet to describe the papers in this manner is to offer an external justification for their content. Far better, surely, to dive in and see how they map onto some parallel scholarly debates, which mainly concern the principles and politics of humanitarian aid.

\section{The challenge of impartiality}

The first paper in this issue, by Hernan Del Valle, explores the debates that took place inside MSF surrounding a decision to launch a programme of search and rescue at sea. Over 3,000 people died in 2015 whilst attempting to cross the Mediterranean, a crisis that was covered extensively in the media, and which became particularly visible after Alan Kurdi, a three-year old Syrian boy, was found dead from drowning on a Turkish beach. This paper concerns the debates that took place earlier in 2015 on how MSF should respond. As Del Valle explains, these discussions centred around a number of crucial issues: whether the operation would be feasible; whether pouring scarce resources into the operation could be justified given the far greater medical needs elsewhere in the world; whether MSF should criticise politicians for causing the crisis in the first place; and whether a search and rescue operation would inadvertently serve the interests of states or human smugglers. In each of these cases, Del Valle illustrates the differences of opinion within the organization and the way these reflected political commitments. He traces the effect of changing circumstances, showing how the centre of gravity in this debate shifted from rejecting search and rescue to finally accepting it as an important element of MSF's response.

At the heart of these discussions lay the complex layers of MSF's identity, particularly its commitment to the 'classical' principles of humanitarian action principles that play a central role in many debates around emergency relief. The roots of these principles go back to the founding of the Red Cross in the middle of the $19^{\text {th }}$ Century; it is only over the last fifty years, however, that they have become codified and referenced in a systematic way. The 1965 international conference of the Red Cross in Vienna was crucial in this regard, proclaiming seven central principles that were later articulated in detail by Jean Pictet in his book The fundamental principles of the Red 
Cross. $^{4}$ Each humanitarian organization has its own articulation of the classical principles, but they tend to revolve around three central ideas: impartiality, neutrality, and independence. Impartiality is the idea that humanitarian assistance should be provided in response to need only, and not according to any other considerations such as race, ethnicity or gender. Neutrality is the idea that humanitarian organizations should stay apart from political and ideological disputes in order to gain the trust of everyone. And independence is the idea that humanitarian agencies should maintain a distinct identity and approach from both state and market - maintaining autonomy in funding streams, policy development, and operational decisions. ${ }^{5}$ MSF subscribes to versions of all three principles, and over the years the organization has had a vibrant series of internal discussions surrounding their application in various difficult circumstances. ${ }^{6}$

Impartiality is a good example. This may be one of the most widely accepted humanitarian principles, but it still leads to tricky operational decisions, especially when needs are difficult to assess and compare. As Del Valle explains in his article, the principle of impartiality led to a series of crucial questions. Does it make sense to pour scarce resources into a search and rescue operation at sea given the far greater needs elsewhere in the world? Would a search and rescue operation in the Mediterranean be consistent with the principle of impartiality, given the vast medical needs across Africa? Since MSF's stock-in-trade is emergency medicine, and their expertise could arguably have a greater impact where malnutrition, infectious diseases and violent trauma are causing high rates of mortality, does it not follow, therefore, that the organization should not be devoting scarce resources to search and rescue missions on Europe’s borders?

\footnotetext{
${ }^{4}$ J. Pictet, The fundamental principles of the Red Cross: a commentary, Geneva, Henry Dunant Institute, 1979.

${ }^{5}$ T. Weiss, "Principles, politics, and humanitarian action", Ethics \& International Affairs, 13(1), 1999, 122. N. Leader, "Proliferating principles; Or how to sup with the devil without getting eaten", Disasters, 22(4), 1998, 288-308. D. Rieff, "Humanitarianism in Crisis", Foreign Affairs, 81(6), 2002, 111-21. A. Donini, "Principles, politics, and pragmatism in the International Response to the Afghan Crisis" in Antonio Donini, Norah Niland and Karin Wermester (eds.), Nation-building unraveled? Aid, peace and justice in Afghanistan, Bloomfield, Kumarian Press, 2004, 117-42. B.A. Rieffer-Flanagan, "Is Neutral Humanitarianism Dead? Red Cross Neutrality: Walking the Tightrope of Neutral Humanitarianism", Human Rights Quarterly, 31 (4), 2009, 888-915.

${ }^{6}$ F. Weissman, V. Homolka, R. Leverdier, and F. Terry (eds.), In the shadow of 'just' wars: violence, politics and humanitarian action, London, C. Hurst, 2004. C. Magone, M. Neuman, and F. Weissman (eds.) Humanitarian negotiations revealed: the MSF experience, London, Hurst, 2011.
} 
Problems surrounding impartiality appear in other papers as well. The article by Sean Healy and Sandrine Tiller, for example, focuses on the practical limitations of impartiality on the ground. Taking the case of Eastern Congo, they describe the way MSF has been providing assistance to internally displaced persons (IDPs) for some years, arguing that it is very difficult to provide aid purely on the basis of need - primarily because so many other factors constantly interfere. The political considerations of the Congolese government, concerns about instability and insecurity, the ability of an organization to negotiate independent access, and the proximity of beneficiaries to a road all play their part. In practice, therefore, humanitarian agencies do not respond purely to needs, but end up skewing assistance towards people who have sought refuge in official camps, those who live in government-controlled areas, people who live along good roads, and those close to the humanitarian agency compound.

Difficulties with acting impartially play out on a global as well as a local level. To return to Del Valle's paper, humanitarian agencies are tasked with comparing the needs of very different populations, in very different places. Judgements about where and how to intervene, therefore, are frequently clouded by emotional attachments, political views, institutional biases, and practical constraints. ${ }^{7}$ Perhaps more significantly, sources of funding may often be tied to a particular crisis, with thousands of dollars per person available in some highly publicised crises, whilst neglected emergencies having no earmarked funding available at all. ${ }^{8}$ Impartiality, in short, faces a great many limitations in practice, and although this should not be taken as grounds for its rejection, it does indicate that there are many other concerns when making such decisions - most notably the long-term possibilities that come from advocacy. Indeed, one of the most illuminating sections of Del Valle's paper explains how the debate around search and rescue involved looking not just at the medical impact, but also the possibilities for raising awareness, promoting longer-term policy change, and advocating for vulnerable people.

\footnotetext{
${ }^{7}$ T. Vaux, The selfish altruist: relief work in famine and war, London, Earthscan, 2001. C. Magone, M. Neuman, and F. Weissman (eds.) Humanitarian negotiations revealed: the MSF experience. London, Hurst, 2011.

${ }^{8}$ S. Healey and S. Tiller, "Where is everyone? Responding to emergencies in the most difficult places", London, MSF, 2014.
} 


\section{Neutrality and politics}

Speaking out in this way, however, is inconsistent with a second 'classical' principle: neutrality. This, to recall, involves maintaining a distance from political disputes and refraining from any act that might be seen as advancing the interests of one side in a dispute at the expense of another. There has long been a tension between neutrality and impartiality, since acting impartially (responding to needs) may in fact contravene neutrality, especially if assistance is interpreted as advancing the interests of one side. Yet there is an even more profound tension between neutrality and advocacy, since speaking out usually involves 'taking sides' in some way. Advocacy seems inherently political, as it often entails condemning the actions of certain groups for abuses or crimes. Most humanitarians nevertheless consider it to be necessary. ${ }^{9}$ After all, neutrality on many issues is morally problematic: to put the point very crudely, a humanitarian should never be neutral between the slave and the slave ship owner.

In making this case, some humanitarians maintain that advocacy is perfectly consistent with neutrality, in the same sense that a referee in a football game is neutral but upholds a set of rules by which all teams must abide. The act of speaking out, in other words, involves reminding the 'players' of these 'rules'. ${ }^{10}$ This is, however, an imperfect analogy. War is not a sport, and the two sides do not necessarily agree on the 'rules' of the game at the outset. The aim of humanitarians when they speak out, moreover, is not just to ensure fair play but also to advocate for the most vulnerable: to advance the cause of people who are suffering. Even if advocacy is articulated in purely moral terms, it demands political action otherwise it has no purpose. The aim of speaking out, in other words, is not simply to affirm the laws of war, but to further the central humanitarian task

\footnotetext{
${ }^{9}$ F. Terry, "The principle of neutrality: is it relevant to MSF ? ", MSF Discussion Paper, 2000. See also M. Harroff-Tavel, "Neutrality and Impartiality? The importance of these principles for the International Red Cross and Red Crescent Movement and the difficulties involved in applying them", International Review of the Red Cross, 29(273), 1989, 536-52. L. Minear, "The theory and practice of neutrality: some thoughts on the tensions", International Review of the Red Cross, 81(833), 1999, 63-71. D. Plattner, "ICRC neutrality and neutrality in humanitarian assistance", International Review of the Red Cross, 36(311), 1996, $161-80$. P. Redfield, "The impossible problem of neutrality" in E. Bornstein and P. Redfield (eds.) Forces of compassion: humanitarianism between ethics and politics, Santa Fe, SAR, 2010, 53-70.

${ }^{10}$ See for example, "Is Humanitarianism Universal? Medical Relief Between Ambition, Principles and Reality” Proceedings of the 7th Humanitarian Congress in the Theory and Practice of Humanitarian Action, November 18-19, 2005, 9. Available at: http://humanitarian-congressberlin.org/files/5513/3974/8772/VII_HumKongress_2005_Dok.pdf (last visited 8 Dec. 2015).
} 
of assisting people in need. This is to engage in a distinctly political form of activism. In short, there is an enduring tension between advocacy and neutrality, and the history of MSF is, in Peter Redfield's words, “the story of how this tension has been constantly negotiated". 11

When the organization was established in 1971, its founders were responding to a perceived failure of neutrality in the Nigerian Civil War. ${ }^{12}$ The 'French doctors' who went on to found MSF had worked in the secessionist territory of Biafra, and disagreed with the traditional, neutral approach of the Red Cross. As in most previous situations, the Red Cross were taking care in public statements, respecting state sovereignty, maintaining discretion, and pursuing a dialogue with both sides. For the 'French doctors', however, this was not enough. They believed there to be a right side and a wrong side, the oppressors (the federal Nigerian side) and their victims (the Biafrans). They had seen the effects of the Nigerian blockade, they had witnessed starvation, disease, and widespread misery. For them, this indicated a fundamental inequality, and staying neutral meant ignoring abuses and supporting the strength of the federal Nigerian government, which already had the diplomatic support of many major powers.

Hanging over this situation was the legacy of the Second World War, which was still a recent memory. In the 1940s, the Red Cross had taken the same strategy with respect to Nazi Germany: care in public statements, respect of state sovereignty, strict neutrality, maintaining discretion, and pursuing dialogue. ${ }^{13}$ By the 1960 s this seemed

\footnotetext{
${ }^{11}$ N. Guilhot, “The anthropologist as witness: humanitarianism between ethnography and critique”, Humanity, 3(1), 2012, 89. P. Redfield, "The impossible problem of neutrality" in E. Bornstein and P. Redfield (eds.), Forces of compassion: humanitarianism between ethics and politics, Santa Fe, SAR, 2010, 53-70.

${ }^{12}$ For more on the history of MSF, see E. Davey, Idealism Beyond Borders: The French Revolutionary Left and the Rise of Humanitarianism, Cambridge: Cambridge University Press, 2015. P. Redfield, Life in crisis: the ethical journey of Doctors without Borders, London, University of California Press, 2013. R.C. Fox, Doctors without borders: humanitarian quests, impossible dreams of Médecins sans frontières, Baltimore, Johns Hopkins University Press, 2014. F. Weissman, "Silence Heals...from the Cold War to the War on Terror, MSF Speaks Out: a Brief History" in C. Magone, M. Neuman and F. Weissman (eds.), Humanitarian negotiations revealed: the MSF experience, London, Hurst, 2011, 177-97. B. Taithe, "Reinventing (French) universalism: religion, humanitarianism and the 'French doctors"', Modern \& Contemporary France, 12(2), 2004, 147-58.

${ }^{13}$ J.-C. Favez, The Red Cross and the Holocaust, Cambridge, Cambridge University Press, 1999. For more on the history of the Red Cross, see D. Forsythe, The humanitarians: the International Committee of the Red Cross, Cambridge, Cambridge University Press, 2005. C. Moorehead, Dunant's dream: war, Switzerland and the history of the Red Cross, London, Harper Collins, 1998. J.F. Hutchinson, Champions of charity: war and the rise of the Red Cross, Boulder, Westview Press, 1996. For more on the implications
} 
unacceptable, even malevolent. The Red Cross had visited the Nazi concentration camps but opted for discretion rather than speaking out, a policy that in retrospect seemed obscene: as its critics pointed out, you cannot be neutral in the face of genocide. For the 'French doctors' working at the front lines in Biafra, history seemed to be repeating itself. They described the Nigerians as committing genocide against the Igbo people of Biafra a claim that was certainly exaggerated, as we can see with the benefit of hindsight. The narrative of the time, however, was helped by the climate of national liberation movements, the resistance to state oppression that emerged from the soixante-huitard generation, and the fact that the Igbo were imagined as the 'Jews of Africa'. ${ }^{14}$ Although the parallels with World War Two were exaggerated, the insufficiency of neutrality was certainly laid bare in Biafra and publicly speaking out became part of MSF's core identity. Such advocacy became known by the French term for testimony or witnessing: témoignage.

In adopting témoignage as a central part of the new organization, however, MSF did not abandon neutrality; this principle remained in the organizational charter, as it does to this day. But it did create an enduring tension that has never really been resolved. ${ }^{15}$ Neutrality, at its heart, involves a distance from politics, a distaste for politics. It seeks to position humanitarians above the grubby, partial, and interest driven world of ideological disputes, situating itself in a pure, impartial, and value-driven world of moral action something articulated very succinctly by Jean Pictet, who declared that humanitarians should "beware of politics as they would of poison, for it threatens their very lives". ${ }^{16}$ Témoignage, on the other hand, involves an engagement with politics, a willingness to take a political stand on the rights and wrongs of a situation. It calls for concerted

for MSF and its history, see R. Brauman, “Dangerous Liaisons: Bearing Witness and Political Propaganda”, MSF CRASH, 2006. Available at: http://www.msf-crash.org/drive/877a-rb-2006dangerousliaisons-(fr-p.14).pdf (last visited 15 Dec. 2015).

\footnotetext{
${ }^{14}$ M.-L. Desgrandchamps, "Dealing with 'genocide': the ICRC and the UN during the Nigeria-Biafra war, 1967-70", Journal of Genocide Research, 16(2-3), 2014, 281-97. D. Chandler, "The road to military humanitarianism: how the human rights NGOs shaped a new humanitarian agenda", Human Rights Quarterly, 23(3), 2001, 678-700. O. Owen, "Biafran Pound Notes", Africa, 79(4), 2009, 570-94.

${ }^{15}$ P. Redfield, "The impossible problem of neutrality." in E. Bornstein and P. Redfield (eds.) Forces of compassion: humanitarianism between ethics and politics, Santa Fe, SAR, 2010, 53-70. F. Terry, "The principle of neutrality: is it relevant to MSF ? ", MSF Discussion Paper, 2000.

${ }^{16}$ J. Pictet, The fundamental principles of the Red Cross: a commentary, Geneva, Henry Dunant Institute, 1979, 56.
} 
political action on behalf of others, creating allies and enemies. This tension does not exist in all humanitarian agencies, but the dual commitment in MSF's charter makes this a particularly distinctive part of the movement. ${ }^{17}$

Neutrality has remained part of the MSF charter mainly for operational reasons: standing apart from political and ideological disputes is seen as a good way to secure trust and gain access to vulnerable populations. The theory is that politicians and armies are more likely to let humanitarians operate freely if they do not see them as a threat to their interests. But the complexity of disasters means that humanitarians can still be manipulated. The incentive of a well-placed aid programme can be used to depopulate areas for counter-insurgency, their presence can be used to attract refugees and create an effective human shield for militias. ${ }^{18}$ Aid, in the end, is a valuable resource in war that can be diverted in legitimate and illegitimate ways for political and military advantage. Many scholars in political science have established the ways in which ostensibly neutral relief operations can have intensely political effects, demonstrating that even if the principle was desirable, it is more or less impossible to achieve. ${ }^{19}$

But the principle is often not seen as desirable. The case against neutrality says, very crudely, failing to condemn people means perpetuating the status quo, it "ratifies the law of the strongest", it refuses "to make a judgement about who is right and who is wrong" and assumes "a legal and moral equality between oppressors and their victims". ${ }^{20}$ Fundamentally, however, neutrality is a flexible principle. It is a means to an end. Staying neutral helps build trust, which helps aid agencies get access to the people in need, which helps them relieve human suffering (which is the final, desirable, end). But when it fails in this task, it ceases to be important. In fact, the practice of most aid agencies indicate that it is a disposable idea: when circumstances demand it, aid agencies seem happy to quietly ditch neutrality, especially when there are many other ways to gain humanitarian

\footnotetext{
${ }^{17}$ A recent articulation of the MSF Charter and Principles is available at http://www.msf.org/msf-charterand-principles (last visited 2 Dec. 2015).

${ }^{18} \mathrm{D}$. Keen, The benefits of famine: a political economy of famine and relief in southwestern Sudan, 19831989, Princeton, Princeton University Press, 1994. For a vivid journalistic take on similar issues, see D. Scroggins, Emma's war: love, betrayal and death in the Sudan, London, Harper Collins, 2003.

${ }^{19}$ A. De Waal, Famine crimes: politics and the disaster relief industry in Africa, Oxford, James Currey, 1997. M. Duffield, Development, security and unending war: governing the world of peoples, Cambridge, Polity, 2007.

${ }^{20}$ F. Terry, Condemned to repeat? The paradox of humanitarian action, London, Cornell University Press, 2002, 22. See also R. Brauman, L’action humanitaire, Paris, Flammarion, 2000, 107.
} 
access. ${ }^{21}$ Neutrality, therefore, is an instrumental rather than an intrinsic good, so the crucial question becomes one of performance: when should a humanitarian agency perform a neutral role, and when should it move into advocacy?

The fascinating part of the debates over search and rescue in the Mediterranean, as recounted by Del Valle, is the way competing performances bubbled under the surface. Whilst accepting that there was a need, and recognising that medical professionals could only have a limited impact when faced with sinking boats, it was nevertheless clear that involvement in the operation could offer important grounds for advocacy, and that this advocacy could, further down the line, relieve suffering. The disputes within the organization, therefore, often came down to whether or not the organization wanted to get stuck into politics in this way. Given the nature of contemporary migration, however, this is an increasingly moribund debate. As most scholars now recognise, aid is inevitably a political act, and the main disagreements concern what kind of politics are involved. ${ }^{22}$ As Del Valle points out, "beyond the unifying commitment to humanitarian ideals, there are significantly different interpretations amongst individuals about the organization's role, and specifically about the limits and purpose of its engagement with the politics and the "migration" debate in Europe". Whether staff in the organization like it or not, these politics inevitably spill into organizational policy, and this is never more obvious than when engaging in advocacy on an issue as divisive as migration and borders.

\section{Borders and suffering}

Témoignage was not the only innovative approach MSF introduced to the humanitarian sector when it was founded in the early 1970s. The other was ingérence, which translates broadly as interference, or a right to intervene. It is an idea intimately connected with MSF's identity as an organization 'without borders', and it is best expressed, once again, as a reaction against the Red Cross, and an opposition to the idea that humanitarian

\footnotetext{
${ }^{21}$ The recent edited collection from MSF sets out many of these alternative strategies in detail. C. Magone, M. Neuman, and F. Weissman (eds.), Humanitarian negotiations revealed: the MSF experience. London, Hurst, 2011.

${ }^{22}$ J. Rubenstein, Between samaritans and states: the political ethics of humanitarian INGOs, Oxford, Oxford University Press, 2015.
} 
organizations have to respect sovereignty, work within existing borders, and seek permission from the state that nominally controlled the territory.

In contrast to the Red Cross, MSF's aim at the outset was to transcend borders. It was prepared to work, if necessary, in territories that were beyond the control of a central government and without their explicit position. ${ }^{23}$ Again, the experience of the NigerianBiafran war was crucial here, as the 'French doctors' felt that seeking federal Nigerian permission to work in Biafra was unnecessarily restrictive. MSF sought, instead, to relieve suffering without permission if the situation demanded it. The aim was to be fast, responsive, to avoid becoming a "stuffy, do-gooding bureaucracy". ${ }^{24}$ There was also a clear moral imperative here, as well as some resonances of the memorable clarion calls of 1968 politics. $^{25}$ The idea was simple: suffering does not respect borders, so neither should relief. ${ }^{26}$

The migration crisis in Europe requires humanitarians to reformulate this slogan. It remains true that suffering does not respect borders, but borders also cause a great deal of suffering. This might sound like a minor change, but it has radical implications. After all, the rationale for setting up 'doctors without borders' has been that borders should be no obstacle to relief. It follows, therefore, that aid agencies had to work around borders, to transcend them. But what should humanitarians do when borders themselves cause so much suffering? Does this not call for a similarly bold move? Does it not follow that aid agencies should call for borders to be opened, or abolished? It is hard to imagine aid agencies making such a radical move, but then again, it is easy to forget how utopian the previous approach was in the 1970s. We are so used to cross-border operations nowadays, as well as familiar with the limitations of sovereignty, that we forget how the

\footnotetext{
23 This later became known as ‘cross-border operations’. H. Slim, and E-C. Gillard. "Ethical and legal perspectives on cross-border humanitarian operations”, Humanitarian Exchange, 59, 2013, 6-10. Available at: http://odihpn.org/wp-content/uploads/2013/11/HE_59_web.pdf (last visited 2 Dec. 2015).

${ }^{24}$ Interestingly, this was also a reason some of MSF's founders left the organization at the end of the 1970 s. J. Benthall, Disasters, relief and the media, London, I.B. Tauris, 1993, 128.

${ }^{25}$ The legacy of 1968 permeated the approach of MSF in the early years. For an account of its influence, see P. Berman, Power and the idealists: or, the passion of Joschka Fischer, and its aftermath, New York, Norton, 2007, 195-246.

${ }^{26}$ R. Fox, "Medical humanitarianism and human rights: Reflections on Doctors Without Borders and Doctors of the World", Social Science \& Medicine, 41(12), 1995. M.I. Ticktin, Casualties of care: immigration and the politics of humanitarianism in France, Berkeley, University of California Press, 2011, 72.
} 
call to offer relief without borders was a courageous and fundamental change. Perhaps, therefore, it is time to think equally radically about how humanitarians should respond to the damaging effect of borders. Perhaps the situation calls for renewed advocacy on the injustice of borders, combined with acts of civil disobedience that allow borders to be crossed illegally on humanitarian grounds.

Explicitly breaking laws remains, however, a step too far for most humanitarian agencies, although a number of papers in this special issue reflect upon the damage caused by borders and the correct humanitarian response. Del Valle's article, for example, suggests that the thousands of deaths in the Mediterranean stand as an indictment of European border policy - whilst also explaining the reluctance of MSF to take such an explicitly political line on the issue. It is a theme that reappears forcefully in Ioanna Kotsioni's paper. Describing MSF's work in detention centres in Greece, she shows the appalling mental and physical cost of widespread immigration detention, critiquing the policy, and exploring the dilemmas that arise from MSF's humanitarian response. Kotsioni's paper articulates the central challenge posed by border regimes for humanitarian action: constrained by international norms and the 1951 Refugee Convention, many states have retreated into policies of deterrence and prevention. Since there is a clear legal obligation for states to hear refugee claims and not to return asylum seekers once they arrive on their territory (the principle of non-refoulement), the past few decades have seen concerted moves to prevent and dissuade refugees from reaching their territory in the first place. These techniques include carrier sanctions, visa regimes, interdiction at sea, and - the focus of Kotsioni's paper - punitive immigration detention. $^{27}$

There is a real contradiction here, since individuals can only get asylum if they have a foot on the soil of a state, yet tight border controls mean that the only way to get to a state and claim asylum is through illegal entry. This contradiction causes so much suffering. Without humanitarian visas or safe passage, asylum seekers will take dangerous journeys to reach their destination, and then, as a result of entering illegally,

\footnotetext{
${ }^{27}$ The impact of borders and suffering is a theme throughout the papers in this issue, but for a particularly interesting operational account of how to overcome such situations, see the paper by Aurélie Ponthieu and Andrea Incerti in this issue.
} 
many will experience punitive detention. As a result, borders cause suffering, becoming a humanitarian concern. They generate deaths at sea, the smuggling industry, the separation of families, the poor treatment of asylum seekers at the hands of police, and the terrible conditions of immigration detention. ${ }^{28}$ Ioanna Kotsioni's paper demonstrates how incarceration fits into this picture, generating and exacerbating anxiety, depression, PTSD, and self-harm.

When defined as a humanitarian problem, therefore, there is only a limited amount MSF can achieve. Indeed, providing medical services in detention centres is one of the clearest examples of the cliché that humanitarian action simply places band-aids on malignant tumours. ${ }^{29}$ When an organization is unable to stop immigration detention, the provision of medical care within detention centres seems terribly inadequate, even an act of collaboration with the authorities. This takes us back to the central question I wish to pose in this introductory paper: how do you respond to suffering migrants without taking a political stand? Quoting Rony Brauman, Kotsioni suggests that MSF has a political responsibility to bear witness to conditions in detention centres. The organization may be severely constrained, she argues. It may be able to relieve only a small amount of suffering. It may even be collaborating in an unjust system. But as long as there is the possibility of achieving policy change through advocacy, there is a clear rationale for such work. As Kotsioni points out, the intervention in Greek detention centres could not be justified without advocacy, and working in these centres offered an unparalleled opportunity to bear witness to suffering and use it for political pressure.

In the end, however, the advocacy itself was constrained by MSF's desire to stay apart from politics. The organizaion "stop[ped] short of challenging the system as such, because to do otherwise would stray to far into the political realm, and would be contrary to the classical humanitarian principle of neutrality". ${ }^{30}$ So although the organization would help raise awareness about the suffering caused by detention, argue for certain people to be released on medical grounds, and make the case for ending the detention of vulnerable groups, it would not explicitly oppose the practice of detention itself. Just as

\footnotetext{
${ }^{28}$ For a useful overview of the varied experiences faced by migrants and asylum seeks on their illegal journeys to Europe, see the paper by Linn Biorklund and Ali Hassan in this issue.

${ }^{29}$ D. Rieff, A bed for the night: humanitarianism in crisis, London, Vintage, 2002, 307.

${ }^{30}$ Paper by Ioanna Kotsioni, in this issue.
} 
Del Valle's paper demonstrated the limits to MSF’s advocacy surrounding rescue at sea, Kotsioni shows how concerns about breaching neutrality constrained the "political responsibility” emphasised by Brauman. The concern in both cases was that MSF might go too far. ${ }^{31}$

\section{Collaboration and refusal}

Another big theme in Kotsioni’s paper is collaboration and refusal. By providing medical care in detention centres, MSF faced the constant risk that they would be perceived to be part of the system. As she explains, MSF was dependent on detention centre staff for basic access: warders would have to unlock patients and accompany them to the medical room for MSF treatment, and from the beneficiary perspective, the people who kept the keys and those that kept the medicines seemed closely aligned - even inextricably linked. MSF, as a result, had to make concerted efforts to demonstrate that the regimes of care and control were, contra Foucault, distinctly different. There remained the fear, however, that Foucault could be right. To care for migrants is also in some sense to control them, and controlling requires a degree of care. ${ }^{32}$ MSF was effectively collaborating with a system it opposed, even though it did so knowingly. Its strategy was to alleviate some of the worst medical conditions in the detention centres, whilst using the opportunity to advocate for improved conditions and speak out against the worst elements of that system.

This strategy, however, was pregnant with risk. Humanitarians back to Florence Nightingale have agonised over similar situations. If you ameliorate the suffering caused

\footnotetext{
${ }^{31}$ It is worth considering that the line any organization 'steps over' may be ideologically drawn. The determination of what is 'too political' for a humanitarian agency is often made by people in power. It might be to the advantage of the humanitarian organization to remain vague and limited in its public ambitions (indeed, there are strong practical grounds for doing so lest this create divisions amongst staff, supporters and donors), but the effective alleviation of suffering, in the end, requires robust political engagement - that is the very point of the high commissioner's adage. To summarise the argument so far, if we see political action as necessity and humanitarian neutrality as a constraint, then the argument that neutrality is a limited, often undesirable, always impossible, and thoroughly contested concept surely leads to a strong case for aid agencies taking a more explicitly political position.

${ }^{32}$ In an earlier version of her paper Kotsioni described a case in which detention centre staff ended up halting a psychosocial programme that involved music and dancing This was on grounds of health and safety and the risk of breaking a limb. This anecdote may not have been fully verifiable, but it shows very clearly how control and care can merge - not to mention the penetrating irony of concern for broken legs in a situation of incarceration.
} 
by a certain activity, you effectively make the costs of that activity easier for the perpetrators to bear. ${ }^{33}$ This has been a common problem for MSF, as staff have often found themselves playing the role of the 'camp doctor': making conditions in confined spaces marginally more acceptable, and, in the process, making confinement and encampment easier to bear for the perpetrators. ${ }^{34}$

The stakes of this situation are spelled out in Hakim Chkam's contribution to this special issue - a paper that examines MSF's long history of working in Dadaab, which is widely known as the largest refugee camp in the world. Drawing on archives and his personal experience working for MSF, Chkam describes how the organization's interventions waxed and waned alongside the changing political environment and the policies of Kenya, the host state. The overwhelming theme in this paper is collaboration and complicity, the way that humanitarian organizations - with varying degrees of awareness and willingness - become tools of the state agenda. Drawing on the age-old dilemma of becoming the 'camp doctor', Chkam describes how MSF programmes could be used as a justification for the containment of refugees, how the provision of medical care in Dadaab could reconfigured as "proof that camps were the 'right' answer to refugee crises" ${ }^{35}$ In this respect, his paper echoes the conclusions of many other authors in this special issue, who show how aid agencies may involuntarily serve the interests of more powerful actors, particularly states. ${ }^{36}$

Chkam's paper introduces a temporal perspective to this debate. In Dadaab, MSF found itself constantly battling new realities, whilst gradually slipping, over the course of a decade, into the management of a protracted refugee situation and facilitating a policy of containment. The usual approach of the organization would be to set up medical services during an emergency and then handover to state authorities for a more sustainable long-term arrangement. In the Dadaab case, however, the Government of Kenya "refused to take over MSF's responsibility for the provision of health care at the Dadaab camps, seeing this as opening the door to the permanent settlement of refugees

\footnotetext{
${ }^{33}$ Florence Nightingale was concerned that the establishment of the Red Cross would make wars easier to fight; if you make wars more humane, she argued, you make them more acceptable. C. Moorehead, Dunant's dream: war, Switzerland and the history of the Red Cross, London, HarperCollins, 1998, 30.

${ }^{34}$ UNHCR, "Policy on Alternatives to Camps", UNHCR/HCP/2014/9, 22 July 2014.

${ }^{35}$ Paper by Hakim Chkam, in this issue.

${ }^{36}$ Papers by Del Valle, Kotsioni, in this issue.
} 
on Kenyan soil”. The result was a humanitarian agency left in limbo, just like the refugees. MSF found itself unhappily facilitating the orderly confinement of a large refugee population, but unable to change anything due to the kind of institutional inertia that accompanies any long-term humanitarian presence. As Chkam writes, MSF staff began describing Dadaab as a "monster”, which “ate” resources and left aid agencies in a stultifying torpor. It left them unable to creatively or effectively question their activities or their presence.

The alternative to collaboration is, of course, refusal, and throughout its history MSF has regularly invoked its right to withdraw, often accompanied by public statements that emphasize the unacceptable conditions in which it has been forced to work. Two of the most famous and dramatic MSF withdrawals were from Ethiopia during the 1983-85 famine, and from Goma during the 1994-96 Great Lakes refugee crisis, but there have been many smaller and less public acts of defiance as well. ${ }^{37}$ Chkam's paper describes how MSF decided to finally close its Dadaab operations in June 2003, and Kosiani describes how an MSF field team ceased its activities after realizing that the realities of detention compromised their work. The closure of programmes may be a routine operation, but it often reflects an organization's unwillingness to work in unacceptable situations, the feeling that an inevitable collaboration has gone too far.

These acts of refusal, so often accompanied by public statements and calls for political action, are, I believe, micro-level examples of the need for a wider form of political engagement. They are small-scale acts of defiance. They represent a refusal to be complicit in the dynamics of a deplorable situation or an uncomfortable compromise. Within MSF, such refusals are widely understood and often invoked, but they are rarely scaled up into a larger act of political disobedience. There is, however, a strong case that they should be. After all, refugee crises are now unfolding on a global level, involving wider forms of complicity that embrace not just containment in Dadaab and detention centres of Greece, but extend to a global system of unequal wealth distribution and punitive border regimes. If we accept that these border regimes are a major cause of human suffering then there may be a duty to oppose them, disobey them, and stand

\footnotetext{
${ }^{37}$ P. Redfield, Life in crisis: the ethical journey of Doctors without Borders, London, University of California Press, 2013, 166-7.
} 
alongside the humans declared as "illegal". Humanitarian agencies doing this will have to take more risks, make unpopular stands, embrace more sacrifices. These acts are difficult to agree upon, and seem to go against the whole history of the humanitarian movement, but such activities are certainly necessary in order to fully stand in solidarity with the world's most vulnerable people.

\section{Acts of solidarity}

Solidarity is a humanitarian principle that is rarely invoked, often confused, but remains a foundational part of the humanitarian movement. Small acts of solidarity take place all the time in the world of aid. Often this kind of solidarity does not need to be broadcast ostentatiously; it can involve technical procedures that, simply and subtly, help people oppose the systems and structures responsible for their suffering. The paper by Aurélie Ponthieu and Andrea Incerti offers a very good example. Through a detailed study of medical services, gaps, and problems for migrant populations in Southern Africa, they describe the difficulty of maintaining continuity of care for migrants - especially those with chronic diseases such as tuberculosis or HIV - and explain how MSF has managed to assist such populations.

At the start of their paper, Ponthieu and Incerti explain why borders are the source of so much suffering. Describing them as not just a "political and legal barrier" for individuals, but also a "high-risk zone for health and dignity", Ponthieu and Incerti demonstrate some of the manifold harms that result from tightened immigration policies in a region that has historically had very high levels of mobility. Irregular migration, they show, leads to labour exploitation, sexual abuse, and discrimination. The paper then shows how some of these problems can be managed by creatively adapting medical services to account for patients' mobility. Tools such as the "health passport", which carries crucial information about diagnoses and treatment regimes, or the "road map", which guides migrants to healthcare facilities on their journey, can help ameliorate the risks that come with human mobility. Such solutions are not spectacular, but they are highly effective and quietly revolutionary. They help individuals to confront the border as an obstacle to their health. They are a quiet act of solidarity. Far from collaborating in 
border regimes by making them easier to manage for states, they collaborate with beneficiaries by helping people work around borders.

This last point is crucial. By refusing to make a distinction between 'legal' and 'illegal' users of their services, MSF's Southern African programmes are effectively negating the power of the state. This programme may look like a collection of purely operational techniques that integrate patients' mobility through tailored models of care, but it also helps patients work overcome the constraints of border control, it resists the categorisations of the state into 'legal' and 'illegal' human beings. This is sansfrontierism at its radical best. The programme is clearly motivated by the idea that suffering is not respecting borders, so neither should the provision of relief, but it also contains the seed of a far more political stance. As Ponthieu and Incerti conclude, "Humanitarians are in a privileged position to assist but also to denounce the source of the suffering they are witnessing: a policy-made humanitarian crisis.” Describing the health crisis around South Africa's border as a 'policy-made crisis' gets right to the stakes. Here, as in many other places, the border is not just a barrier to suffering, it is an explicit cause of that suffering. A humanitarian response, therefore, does not just mean ignoring the border, it means denouncing the border as well.

Del Valle, who writes about the division between 'deserving refugees' and 'undeserving migrants', echoes this refusal to distinguish between 'legal' and 'illegal' beneficiaries. He points out that the refugee regime may have been a useful way to generate legitimacy for humanitarian activities in the past; it may have offered a legal basis for assistance to individuals fleeing violence and provided solid grounds for advocacy on beneficiary rights in host states, but in the European context, the refugee regime is also responsible for categorising people into migrants and refugees. This, Del Valle suggests, is a distinction MSF does not wish to share. ${ }^{38}$ Just as MSF in Southern Africa programme would not distinguish between 'legal' and 'illegal' users of their clinics, MSF in Europe would not distinguish 'deserving refugees' and 'undeserving migrants'. The reason is simple. If humanitarianism is to mean anything, it must mean

\footnotetext{
${ }^{38}$ This division was not such an evident problem for humanitarian agencies when they were working outside Europe in those 'mass influx' situations where all people tended to be declared prima facie refugees.
} 
responding to humans qua humans, not humans qua 'refugees', 'migrants', 'legal citizens' or 'illegal aliens'.

Both stances - by MSF in Southern Africa and in Europe - are manifestations of the principle of solidarity, which is best thought of as the notion that humanitarians respond to people as fellow humans. It involves rejecting categorizations that get in the way of standing shoulder to shoulder with victims, and it is a very important part of the humanitarian movement. Stephen Hopgood describes humanitarianism as being fundamentally about "solidarity with suffering" rather than simply meeting needs. ${ }^{39}$ Andrea Paras and Janice Gross Stein portray humanitarian relief as "both a demonstration of human solidarity and an enactment of sacred moral principles”. ${ }^{40}$ Fiona Terry has written how "humanitarian action is more than just a technical exercise aimed at nourishing a population defined as 'in need', but is a moral endeavour based on solidarity with other members of humanity". ${ }^{41}$ This is certainly a significant motivation for many individuals within MSF, for whom "the individual act of providing medical assistance is an act of bearing witness and thus of human solidarity”. Indeed, a recent MSF book has described medical humanitarian action as "an act of human solidarity, provided by an impartial, independent and neutral organization, without any hidden agenda”. ${ }^{2}$

The idea of solidarity is everywhere in humanitarianism, but it is rarely promoted or discussed - certainly not to the same extent as neutrality or impartiality. This is partly due to confusion: there are two competing definitions that seem almost at odds with one another. $^{43}$ The first definition is the one that appears in all the quotations above. It

\footnotetext{
${ }^{39}$ S. Hopgood, "Saying 'no' to Wal-mart? Money and morality in professional humanitarianism." in M. Barnett and T.G. Weiss (eds.), Humanitarianism in question: politics, power, ethics, Ithaca, Cornell University Press, 2008, 113.

${ }^{40}$ A. Paras, and J.G. Stein, "Bridging the sacred and the profane in humanitarian life" in M. Barnett and J.G Stein (eds.), Sacred aid: faith and humanitarianism, Oxford, Oxford University Press, 2012, 229.

${ }^{41}$ F. Terry, “The principle of neutrality: is it relevant to MSF?", MSF Discussion Paper, 2000, 3. Available at: http://www.msf.fr/sites/www.msf.fr/files/2000-12-01-Terry.pdf (last visited 1 Dec. 2015).

${ }^{42}$ Paras and Stein, "Bridging the sacred and the profane in humanitarian life", 237. C. Abu-Sada and K. Mambetova,"Reversing the Optics: MSF's perception project" in C. Abu-Sada (ed.), Dilemmas, challenges, and ethics of humanitarian action: reflections on Médecins Sans Frontières' Perception Project, Montreal, McGill-Queen's University Press, 2012, $11-12$.

${ }^{43}$ For discussions of solidarity as a humanitarian principle, see P. Walker, and D. Maxwell, Shaping the humanitarian world, London, Routledge, 2009, 122-123. L. Minear, The humanitarian enterprise: dilemmas and discoveries, Bloomfield, Kumarian Press, 2002, 79. L. Fast, Aid in danger: the perils and promise of humanitarianism, Philadelphia, University of Pennsylvania Press, 2014, 98. T. Weiss,
} 
embraces solidarity to all humans by virtue of their common suffering. This is best encapsulated by Hopgood's phrase "solidarity with suffering”, which presents solidarity as an extension of the humanitarian imperative itself, demonstrating no conflict with the other classical principles. We might call this idea 'universal solidarity'. ${ }^{44}$ It is perfectly compatible with neutrality and impartiality.

The second definition of solidarity, however, extends to particular humans, those who are disproportionately defined by their suffering. It involves 'taking sides', identifying and supporting a 'wronged' party. This involves rejecting classical principles such as neutrality, and directing resources towards oppressed and victimised groups. ${ }^{45}$ It often arises to distinguish certain "solidarist" humanitarian organizations, which take an explicitly political stand, from those “classicist" or "Dunantist" agencies, which are committed to classical ideals. ${ }^{46}$ We might call this "inclusive solidarity”. ${ }^{47}$

Universal solidarity is such a central part of humanitarian action that it is hardly worth articulating. Inclusive solidarity, however, is so rarely defended that it is often misunderstood. For most humanitarian agencies, standing in solidarity with certain groups is dangerous and difficult. As Hugo Slim has argued, it is only possible when the oppressed group are clearly identifiable and have an clearly just cause - something rare in contemporary conflicts, where it is very difficult to distinguish the 'right' from the

\footnotetext{
"Principles, politics, and humanitarian action", Ethics \& International Affairs 13(1), 1999, 3-4. Some of these authors use the first definition of solidarity, others use the second.

${ }^{44}$ The ideas of 'universal' and 'inclusive' solidarity used in this paper comes from K. Reshaur, "Concepts of Solidarity in the Political Theory of Hannah Arendt", Canadian Journal of Political Science, 25(4), 1992, 723-36. I am grateful to my colleague Cathryn Costello for drawing my attention to this article and for discussions about solidarity.

${ }^{45} \mathrm{H}$. Slim, "Relief agencies and moral standing in war: principles of humanity, neutrality, impartiality and solidarity", Development in Practice, 7(4), 1997, 342-52. See also H. Slim, "Doing the Right Thing: Relief Agencies, Moral Dilemmas and Moral Responsibility in Political Emergencies and War", Disasters, 21(3), 1997, 244-57.

${ }^{46}$ The term 'classicist' comes from Weiss, "Principles, politics, and humanitarian action", Ethics \& International Affairs, 13(1), 1999, 1-22. The term 'Dunantist' derives from Henri Dunant, the founder of the Red Cross and arguably the father of classical principles, and the term was originally used in A. Stoddart, "Humanitarian NGOs: Challenges and Trends", Humanitarian Policy Group Briefing, 12, July 2003. Available at: http://www.odi.org/sites/odi.org.uk/files/odi-assets/publications-opinion-files/349.pdf (last visited 3 Dec. 2015) See also M. Barnett, The international humanitarian order, London, Routledge, 2010, 181-182.

${ }^{47}$ This definition of solidarity is 'inclusive' because it includes the privileged and fortunate standing in solidarity with the oppressed. In contrast, 'exclusive' solidarity refers to solidarity within an oppressed group, who are coming together against their oppressors.
} 
'wrong' side. ${ }^{48}$ 'Inclusive solidarity', however, should be thought of as far more complex than Slim gives it credit for. Norwegian People's Aid (NPA), for example, is perhaps the best known agency organized around explicitly solidarist lines, but it would not identify its work so crudely as simply "taking sides". The approach of NPA, rather, is to recognise that suffering is rooted in socio-political conditions, and that its aid has socio-political effects. In the words of Eva Bjøreng, former Secretary-General, it involves accepting that all humanitarian organisations are political and social actors, and harnessing that fact to good ends. As she puts it, "whoever controls and distributes resources in a society marked by scarcity, conflict, injustice or oppression, [will] play a political role". ${ }^{49}$ Decisions regarding "who to help, where to help and what to do to help", therefore, need to be taken carefully as they have a political impact far beyond the project intentions. Solidarist organizations, as a result, do not simply 'take sides', but try to think carefully about how to use their resources to realise their political values, such as justice, equality, and democracy.

\section{Rethinking solidarity}

In the midst of the migration crisis, aid organizations such as MSF find themselves at a crossroads. They can hold onto neutrality and impartiality, or they can question these principles entirely. In support of the second option, David Rieff wrote a few years ago that "humanitarian space is a sentimental idea, neutrality a bogus one, and impartiality an abstraction, however necessary, and it is a lost cause to defend any of them”, concluding that "the sooner they're given a decent burial, the sooner we can all move on". ${ }^{50}$ His words formed the afterword to an MSF collection that discussed the fallibility and flexibility of the "classical principles" in practice, giving substance to a view long held by scholars that political and humanitarian action "cannot and should not be separated" ${ }^{51}$ In this afterword, Rieff proposed to elevate, as an alternative to neutrality and

\footnotetext{
${ }^{48}$ Slim, "Relief agencies and moral standing in war”, 349.

${ }^{49}$ E. Bjøreng, "Taking a Stand: Solidarity and Neutrality in Humanitarian Action”, Humanitarian Exchange, 25, December 2003, 9-11. Available at: http://odihpn.org/wpcontent/uploads/2003/12/humanitarianexchange025.pdf (last visited 5 Dec. 2015).

${ }^{50}$ D. Rieff, "Afterword" in C. Magone, M. Neuman and F. Weissman (eds.), Humanitarian negotiations revealed: the MSF experience, London, Hurst, 2011, 254.

${ }^{51}$ Weiss, "Principles, politics, and humanitarian action", 2.
} 
impartiality, the principle of autonomy, which he suggested was easier to define and monitor. The advantage of autonomy, Rieff argued, is that it is "essentially transactional". It requires a clear strategy for success. “One does not simply assert one’s autonomy, one defends it". 52

This may be true, but solidarity is even more useful as an organizing principle for humanitarian relief. Autonomy may have the advantage of being transactional, but it is still, fundamentally, a dissociative principle. It holds others at a distance, articulating a separation of the aid agency from other actors. Solidarity, however, is fundamentally associative. It requires multiple connections with others. It also reflects the most basic motivations of aid workers: to show vulnerable people they have not been forgotten. As Kotsioni points out in her paper, the very presence of MSF teams in many places has an important impact, and "the mere fact of treating the detained migrants in a humane and dignified way countered the widespread feeling amongst detainees that they had been forgotten and rejected by society." Whereas autonomy is an instrumental good - valuable mainly for what it allows aid workers to achieve - solidarity, without doubt, is a solidly intrinsic good: valuable as an end in itself.

In the final paper of this special issue, Ali Hassan and Linn Biörklund demonstrate the importance and challenge of solidarity for humanitarians. Based on the detailed narrative of a refugee's journey from the Middle East through the Balkans to Sweden, the article demonstrates the complexity of an individual's suffering and explores some of the challenges and emotions from the refugee's perspective. Written in the first person and constructed as a life history of Ali Hassan (based on interviews by Linn Biörklund), the paper describes a route to Europe that has recently become the most travelled path for Syrian refugees coming to Western Europe. It documents the hardships faced by Ali Hassan on this journey, from being exploited by smugglers to being detained in transit. These remain an important part of the lived experience of refugees in Europe today.

How should humanitarians respond to this situation? Hassan and Biörklund's paper points out that assistance in these situations is far more complex than in traditional

\footnotetext{
${ }^{52}$ Rieff, "Afterword." 254.
} 
camp settings. ${ }^{53}$ The situation is more diffuse, the problems generally hidden, and, in their words, "it is significantly easier for humanitarian agencies to deliver care, organize logistics and establish health surveillance systems for a contained population than a dispersed and/or mobile one”. Unlike in camp settings, aid agencies cannot fall back on their procedures. They cannot become managers or subcontractors for states. ${ }^{54}$ To really assist in the alleviation of suffering they need to help 'illegal' people complete their journey safely, and as a result, solidarity becomes all the more important. This is not just a matter of finding and assisting people who are trying to remain underground. Nor is it simply a matter of advocacy, pointing out that this is, to use Ponthieu and Incerti's term once again, “a policy-made humanitarian crisis”. A meaningful humanitarian response means acknowledging that legality or illegality is irrelevant to human suffering, and that it may also be irrelevant to relief.

\section{Conclusion}

Over recent years, solidarity with migrants has become increasingly criminalised. The case of Cap Anamur, which is described by Del Valle in this issue, is just one of many examples. Humanitarian action has been constrained by legal measures that criminalise transportation and assistance, and many humanitarian attempts to help people cross borders have become classed as human smuggling. ${ }^{55}$ This forces aid agencies to make a choice. They either change their activities in order to comply with the law, or they become more oppositional. The first option leads to such a constrained humanitarian imagination in which solidarity all but disappears, whereas the second option involves recognising that true solidarity means taking unpopular stands and even breaking the law. Taking the first route means rescuing people at sea, but not helping them complete their journey; it means assisting people who are in immediate peril, but leaving them if their suffering is not acute. This route, however, does not constitute solidarity in any meaningful sense. The more that law and political discourse constrains what

\footnotetext{
${ }^{53}$ Many humanitarian procedures were originally developed in camps. See P. Minn, "Towards an anthropology of humanitarianism”, The Journal of Humanitarian Assistance, August $6^{\text {th }}$ 2007. Available at: https://sites.tufts.edu/jha/archives/51 (last visited 4 Dec. 2015).

${ }^{54}$ Paper by Hakim Chkam, in this issue.

${ }^{55}$ L. Fekete, "Europe: crimes of solidarity", Race \& Class, 50 (4), 2009, 83-97.
} 
humanitarians do, the more they need to consider the second route: acknowledging that true human solidarity involves resistance and political action in the face of complicity by nation-states.

From the papers in this special issue, it seems clear that traditional humanitarian responses are facing a profound challenge as a result of human mobility and the rising number of refugees. From Greece to South Africa, Kenya to the Congo, the papers show that it is becoming increasingly difficult, if not impossible, to take effective humanitarian action in response to migration without also taking a clearly political stand. The problem might be defined as one of "humanitarianization": an ugly word that helps describe how political issues are becoming reconfigured as humanitarian ones. As I indicated in the introduction, the key issue in contemporary humanitarianism, I believe, is not that humanitarian solutions are insufficient - although this is certainly an important observation to make. The far more central issue is that humanitarian problems are not sufficient; that framing an issue as a distinctly humanitarian one necessarily limits the responses available. The problem with the high commissioners' adage (the idea that, in the end, there are no humanitarian solutions to humanitarian problems) is that it focuses attention on the wrong side of the equation. It makes us think that the solutions are wrong. In fact, what's wrong is the articulation of problems.

Indeed, if we look at the high commissioner's adage for any length of time, we begin to see how strange it really is. In other sectors, this kind of formulation would not really work. It would not make sense for anyone in the education sector to declare that there are no pedagogical solutions to pedagogical problems, or for a nutritionist to declare that there are no nutritional solutions to nutritional problems. This is because we instinctively know that the way we frame issues leads naturally to particular types of solution. ${ }^{56}$ Indeed, framing something as a nutritional problem makes it amenable to a nutritional solution; framing something as a pedagogical problem makes it amenable to a

\footnotetext{
${ }^{56}$ Foucault's work on "problematizations”, of course, makes a similar point. See M. Foucault, "Polemics, Politics and Problematizations" in P. Rabinow (ed.), The Foucault Reader, New York, Pantheon, 1984, 3835. It is cruel but correct to point out that problems are a quintessentially humanitarian pass time. You do not generally find discussion of human rights problems; you find discussion of human rights violations. Human rights is a robust language of blame and responsibility, in which human rights advocates know right from wrong and have a substantive vision of a better global society. Humanitarians, on the other hand do not. Their focus is narrower, more restricted to the relief of suffering. Their default is uncertainty, dilemma, and angst.
} 
pedagogical solution. So why is humanitarianism an exception? After all, there are humanitarian solutions to humanitarian problems, but the more important question is how certain problems come to be framed as specifically humanitarian ones in the first place, and what is the impact of doing so?

The papers in this special issue indicate some serious implications of articulating a problem in humanitarian terms. Describing something a humanitarian crisis is a bit like declaring an emergency: it facilitates certain forms of action, but disallows others; it enables us to think of an issue in one way, but not in another. In this respect, the declaration that "there are no humanitarian solutions to humanitarian problems" could be conceived as a far more radical slogan. After all, it questions the very idea that we can bracket off certain events to be treated using humanitarian protocol.

In a different context, Rony Brauman has lamented the way that certain events such as genocide in Rwanda or massacres in Bosnia - become described as a 'humanitarian crisis'. "The UN as well as governments, the press, and the NGOs”, he wrote, "are constantly using this formula, which leads me to wonder if Auschwitz would be considered a 'humanitarian crisis' were it to happen today". ${ }^{57}$ By drawing attention to such an extreme example, Brauman makes it clear why it is so distasteful to 'humanitarianize' certain issues. Auschwitz, where human depravity reached new depths, should not be thought of as a humanitarian crisis because to do so would be to detract from the horror, the culpability, the ideological and political function of the place, as well as trivialise the suffering. The stakes of the migration crisis are not nearly so high, but the challenge is similar, because in many ways this cannot, and should not, be thought of as a humanitarian crisis at all. It is a political crisis, and framing it as a distinctly humanitarian one just limits the responses available.

My argument is not that humanitarians should disengage, but rather that they should rethink their purpose along the lines of a genuine human solidarity. As Henry Radice has pointed out, "MSF's vision of politics is best summarized as a refusal to tolerate suffering. The organization's claim to political autonomy ultimately rests on a

\footnotetext{
${ }^{57}$ R. Brauman, Humanitaire, le dilemme, Paris, Editions Textuel, 1996, 76. Translation from A. Grzyb, The world and Darfur: international response to crimes against humanity in Western Sudan. Montreal, McGillQueen’s University Press, 2009, 265. See also Redfield, Life in Crisis, 123. Rieff, A Bed for the Night, 75.
} 
technical - medical - engagement with that suffering”. ${ }^{58}$ I think it is time to move beyond this purely technical engagement, valuing acts of solidarity more explicitly. Indeed, many of the papers in this special issue show how the benefits of MSF's work cannot be reduced to purely technical acts; they cannot all be fitted into a calculus of medical relevance. Kotsioni's paper is a good example, as she indicates the combination of activities that produce a result. Some of these are medical, some are political, but others are very difficult to define. In her words, it was the "provision of medical care and essential relief to a population that otherwise might not have access to it, a protective effect that came from witnessing, and the restoration of beneficiaries' dignity" which combined to create an impact that should not be underestimated. She goes on: "the mere fact of treating the detained migrants in a humane and dignified way countered the widespread feeling amongst detainees that they had been forgotten and rejected by society. For many aid workers, this aspect of MSF's action had perhaps the deepest humanitarian significance of all.”

\footnotetext{
${ }^{58}$ H. Radice, "Book review: humanitarian negotiations revealed: the MSF experience, edited by Claire Magone, Michaël Neuman, and Fabrice Weissman; and, humanitarian reason: a moral history of the present by Didier Fassin”, Ethics and International Affairs, 26(4), 2013.
} 